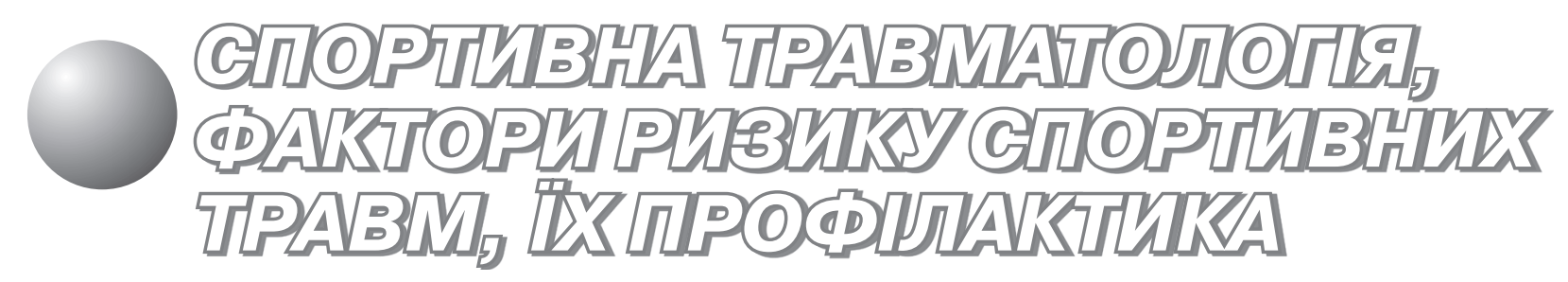

DOI: https://doi.org/10.32652/spmed.2020.2.26-30

\title{
Особливості застосування засобів фізичної терапії у осіб з пошкодженням Ахіллового сухожилля у передопераційному періоді
}

\author{
УДК: 616.748-085:616-089 \\ О. К. Ніканоров, В. Б. Заєць
}

Национальный университет физического воспитания и спорта Украины, Киев, Украина

Резюме. Мета. Розробити алгоритм застосування найбільш ефективних засобів реабілітації на етапі передопераційної підготовки хворих з пошкодженням Ахіллового сухожилля. Матеріал і методи. Було обстежено 120 хворих віком $41 \pm 11$ р. з підшкірним пошкодженням Ахіллового сухожилля. Обстежувані були розподілені на дві групи: в першій групі $(\mathrm{n}=50)$ проводили стандартну передопераційну підготовку, у другій групі $(n=70)$ використовували розроблений нами підхід відповідно до стадій перебігу регенеративного процесу в організмі (застосовували лікувальну гімнастику, масаж, фізіотерапевтичні та фармакологічні методи, локальну санацію місця операції). Пацієнти обох груп під час госпіталізації крім обстеження зони ураження (МРТ, ультразвукове дослідження, рентгенографія) проходили додаткові обстеження: рентгенографію поперекового відділу хребта, обстеження за шкалою AOFAS та Boyden; визначали обсяг рухів у надп'ятково-гомілковоюому суглобі, силу м'язів згиначів/ розгиначів стопи, проводили антропометрічне вимірювання мінімального та максимального діаметра гомілки, подометрію, подографію за Штретгаром; визначали швидкісну витривалість згиначів стопи, здатність стояти на пальцях стопи, опороздатність кінцівки на місці ураження та на здоровому боці. Висновки. Комплексне використання засобів фізичної реабілітації має переваги порівняно з окремим використанням різних методів відновлення. Тільки за умови систематичного раціонального та комплексного застосування засобів фізичної реабілітації вдається усунути негативні наслідки пошкодження та покращити рухову активність.

Результати аналізу дозволяють зробити висновки, що успішне проведення лікувальновідновних заходів потребує участі широкого кола спеціалістів, котрі об'єднані у мультидисциплінарну бригаду з чіткою узгодженістю та координованістю дії для забезпечення цілеспрямованого підходу в реалізації завдань реабілітації.

Ключові слова: предопераційна реабілітація, Ахіллове сухожилля, алгоритм лікувальновідновних заходів.

Particular qualities of the use of physical therapy methods in patients with rupture of the Achilles tendon in the preoperative period.

O. K. Nikanorov, V. B. Zaiets

National University of Physical Education and Sports of Ukraine

Abstract. Objective. To develop an algorithm for the application of the most effective methods of rehabilitation at the stage of preoperative training of patients with subcutaneous injury of the 
Achilles tendon. Materials and methods. We examined 120 patients with subcutaneous rupture of the Achilles tendon, aged $41 \pm 11 \mathrm{p}$. The patients were divided into two groups. The first group consisted of 50 people who received standard preoperative training. In the second group, 70 people used the approach developed by us according to the stages of the regenerative process in the body (therapeutic exercises, massage, physiotherapeutic and pharmacological methods, local sanitation of the operation area were used). On admission, patients of both groups underwent additional examinations in addition to examination of the damaged area (MRI, ultrasound, radiography): radiography of the lumbar spine, examination using the AOFAS and Boyden scale, determined the range of motion in the ankle joint, the strength of the flexor / extensor muscles of the foot, and anthropometric measurements minimum and maximum diameter of the shin, podometry, podography behind Stretgar, speed endurance of the flexors of the foot, the ability to stand on the toes, support ability of the limb on the side of injury and on the healthy side. Conclusions. The complex use of physical rehabilitation methods has advantages in comparison with the separate use of different methods of recovery. Only with a systematic rational and comprehensive application of physical rehabilitation methods is it possible to eliminate the negative consequences of injuries and improve physical activity. The results of the analysis allow us to conclude that the successful implementation of diagnostic and treatment procedures requires the participation of a wide range of specialists, who are united in a multidisciplinary team with clear consistency and coordination of actions to ensure a targeted approach in the implementation of rehabilitation tasks.

Key words: preoperative rehabilitation, Achilles tendon, algorithm of treatment and rehabilitation methods.

Постановка проблеми. Частота підшкірного розриву Ахіллового сухожилля за даними ряду авторів становить 25-30 випадків на 100 тис. населения в рік та продовжує зростати. Чоловіки отримують травму в 6-9 разів частіше за жінок. Страждає переважно працездатне населення віком від 30 до 50 років. До 70-90 \% пошкоджень виникає під час занять «спортом вихідного дня». До $20 \%$ випадків діагностуються через 4 тиж. та більше від моменту травми, що призводить до виникнення дегенеративних змін у трицепсі гомілки і п'ятковому сухожиллі та зниження ефективності лікування. Водночас, серед відкритих пошкоджень на перше місце виходить побутова травма (пошкодження склом) - $58 \%$, на друге місці виробнича $-23,8 \%[1,2,14]$.

На сьогодні сучасні системи відновлення у разі пошкодження Ахіллового сухожилля не мають спеціалізованого характеру, не враховують спеціалізацію та пов'язану з цим необхідність відновлення специфрічних навичок та вмінь [11-13]. Відсутні чіткі алгоритми застосування найбільш ефективних засобів реабілітації з урахуванням почергового їх включення на різних етапах відновного процесу, не розроблені чіткі критерії для переходу з одного функціонального методу до іншого. Крім того, розвиток новітніх способів у сучасній хірургії вимагає перегляду реабілітаційних технологій з урахуванням малоінвазивності оперативного втручання, специфічності методів фрізичної реабілітації, можливості ранньої розробки рухів у надп'ятково-гомілковому суглобі та навантаження на прооперовану кінцівку, скорочення періоду відновлення $[6-8,15]$. Терапевтичний есрект від тренування можливий у разі збережен- ня таких умов, як системність дії певним чином підібраних фрізичних вправ та їх послідовність; регулярність застосування; тривалість вправ протягом курсу відновлення. Під час вибору вправ необхідно чергувати м'язеві групи, що задіяні у виконанні фрізичних вправ, поступово збільшувати навантаження протягом окремо взятої процедури та протягом всього курсу відновлення, постійно частково оновлювати вправи з метою урізноманітнення та розширення методики, індивідуалізувати вправи залежно від особливостей захворювання, віку, статі, стану здоров'я окремого пацієнта.

Ряд досліджень довів, що регулярні заняття фрізичними вправами сприяють збільшенню об'єму м'язів за рахунок товщини м'язевих волокон, впливають на тонус м'язів та можливість створення довготривалого статичного зусилля та напруження, що чергуються 3 розслабленням; зберігається еластичність та рухливість капсульнозв'язочного апарату суглобів, що сприяє профрілактиці розвитку тугорухливості, м'язевій атрофіï, утворенню контрактур. Фізичні вправи рекомендують поділяти за анатомічною ознакою (вправи для верхніх кінцівок та плечового пояса, м'язів спини, брюшного преса, тазового дна, шиї, нижніх кінцівок) та за ступенем активності (активні, які виконує сам пацієнт, та пасивні, що виконуються за допомогою спеціаліста з фрізичної реабілітації) [9-11]. Основна мета застосування пасивних вправ - це підготовка пацієнта до активних вправ; також вони затримують розвиток дегенеративних змін, що виникають під час патогогічного процесу. Фізіологічна дія їх полягає у сприянні ффункціонуванню «м'язевого насоса», що покращує трофріку на перифрерії. Пасивні впра- 
ви сприяють підтриманню нормальної довжини та еластичності м'язів, діють на центральну нервову систему через активізацію провідних шляхів, головним чином пропріоцептивних, що досягається за рахунок збільшення внутрішньосуглобового тиску або вільного розтягнення м'язів, а також подразнення екстерорецепторів шкіри [3-5].

Отже, вказане $є$ важливою основою для науково-практичної розробки методів корекції патологічно зміненого морфофункціонального стану м'язів, оскільки пасивне розтягнення-напруження має змогу гальмувати протеоліз та стимулювати відновлення денервованих м'язів.

Мета дослідження - розробити алгоритм застосування найбільш ефективних засобів реабілітації на етапі передопераційної підготовки хворих з пошкодженням Ахіллового сухожилля.

Матеріал і методи дослідження. Було обстежено 120 хворих віком $41 \pm 11$ років з підшкірним пошкодженням Ахіллового сухожилля. Переважали чоловіки (5:1). Пошкодження правого Ахіллового сухожилля відбувалось частіше, ніж лівого (4:3). Механізм підшкірних пошкоджень активізувався внаслідок непрямої травми у 68,6 \% випадків, у більшості під час стрибка, значно рідше розрив виникав під час приземлення або фрорсованого кроку назад - 5 \%. У $12 \%$ випадків розрив виникав від прямої травми. У 19,4 \% усіх підшкірних розривів пошкодження виникали через незначні травми під час звичайної ходьби. Перше місце серед причин підшкірних розривів займає спортивна травма - 38,3 \%. Частіше за все під час гри у футбол, волейбол, баскетбол, гандбол, занять легкою атлетикою, гімнастикою. При цьому третина хворих займалась спортом професійно.

Під час передопераційного обстеження у 70,9 \% пацієнтів 3 непрямою травмою було діагностовано дегенеративно-дистрофрічні зміни на рівні поперекового відділу хребта. В ході гістологічного дослідження тканин, що були взяті у пацієнтів з підшкірним розривом Ахіллового сухожилля, було виявлено, що у 97,9 \% хворих розрив відбувся на фооні дегенеративно-дистрофрічних змін тканини сухожилля. Відповідно до проведених досліджень у 21,3 \% пацієнтів підшкірний розрив Ахіллового сухожилля було діагностовано не відразу.

У ранній період після травми (перші 7 днів) має місце крововилив у підшкірну клітковину та прилеглі тканини, кінці сухожилля сильно розволокнені, це відбувається тому, що хід волокон сухожилля спиралеподібний і розриви відбуваються на різних рівнях спіралі. Діастаз між кінцями сухожилля невеликий, до 2 см.
Через 2 тиж. після травми діастаз між кінцями сухожилля збільшується до 4 см, кінці сухожилля інфільтровані, мають фрібринові нашарування, місцями залишаються ущільнені згустки крові та кистоподібні утворення на місці гематоми. Через 4 тиж. після травми гематома зорганізується, формується сполучнотканинний рубець, що з'єднує кінці Ахіллового сухожилля, товщина рубця від 15 до 20 мм. У перші 2 міс. сполучна тканина нещільна, легко руйнується. Після 6-го тижня $з$ моменту травми відстань між кінцями розірваного сухожилля становить 6 см, між ними знаходиться сполучна тканина завтовшки 20 мм, яка за щільністю наближається до самого сухожилля. Обсяг та характер засобів відновлення, що використовують під час програмування процесів фрізичної реабілітації, залежать від часу після отримання травми, оскільки посттравматичне відновлення м'яких тканин відбувається у три стадії (за Г. Гайслер та М. Вилсон): стадія гострого запалення (триває 3 доби), характеризується запальною реакцією, болем, гіперемією, набряком, підвищенням локальної температури. Гістологічна картина характеризується фрагоцитозом некротичних клітин, відбувається міграція фрібробластів у вогнище ураження. Стадія друга, фраза регенерації та відновлення, триває з 3-ї доби до 6-го тижня. У цей період утворюється рубцевий коллаген. Відбувається перебудова та регенерація структури тканини. Фібробласти, котрі мігрували у вогнище ураження, продукують колаген II типу. Стадія третя, фраза ремоделювання, триває з 3-го тижня до 12 міс. Загальний вміст колагену в регенерованій тканині поступово знижується, рубець розсмоктується, набуваючи властивості тканини, що була пошкоджена. Час повного відновлення залежить від ступеня тяжкості пошкодження.

На передопераційному етапі підготовки хворого ми мали справу з першою та другою стадіями регенерації. Основні завдання на першій стадії - це купування больового синдрому, зменшення набряку, іммобілізація травмованої кінцівки, стимулювання процесів загоєння. На другій стадії основними завданнями є підтримання рухливої фрункції, збільшення амплітуди рухів у суглобах, збільшення м'язової сили, місцевої витривалості, збільшення аеробних властивостей організму, підвищення рівня пропріорецепції, балансу та координації.

Обстежувані хворі були розподілені на дві групи. У першій групі ( $=50)$ проводили стандартну передопераційну підготовку (профрілактика загострення хронічних захворювань, та ранніх ускладнень у післяопераційному періоді), у дру- 
гій групі $(n=70)$ використовували розроблений нами підхід відповідно до стадії перебігу регенеративного процесу в організмі (застосовували лікувальну гімнастику, масаж, фрізіотерапевтичні та фармакологічні методи, локальну санацію місця операції). Пацієнти обох груп під час госпіталізації крім дослідження зони ураження (МРТ, ультразвукове дослідження, рентгенографрія) проходили такі додаткові обстеження, як рентгенографія поперекового відділу хребта, обстеження за шкалою AOFAS та Boyden, визначення обсягу рухів у надп'ятково-гомілковому суглобі та сили м'язів згиначів/розгиначів стопи; також проводили антропометрічне вимірювання мінімального та максимального діаметра гомілки, подометрію, подограсрію за Штретгаром; визначали швидкісну витривалість згиначів стопи, здатність стояти на пальцях стопи, опороздатність кінцівки на місці ураження та на здоровому боці. Повторне обстеження (за винятком ультразвукового, МРТ дослідження та рентгенографії хребта) проводили за 5 днів перед оперативним втручанням. У другій групі під час підготовки до оперативного втручання проводили легкий масаж гомілки, дихальну гімнастику, активні та пасивні рухи в надп'ятково-гомілковому суглобі, ізометричні вправи для квадрицепса стегна та трицепса гомілки, активні рухи у кульшовому суглобі та пальцях стопи, призначали аскорбінову кислоту у дозі 1 г на добу, 15 днів; діклофенак натрію 75 мг внутрішньом'язово, № 5; внутрішньовенно актовегін $10 \mathrm{мг} \mathrm{на} 100$ мл ізотонічного розчину натрію хлориду, № 5; на місце розриву УВЧ-терапія, № 5. Протипоказаннями до включення в другу групу були: підвищення температури понад $38^{€} \mathrm{C}$; наявність гнійного або запального процесу; загострення соматичних захворювань, викликане травмою; небезпека виникнення вторинної сильної кровотечі. Також було застосовано раціональну роз'яснювальну психотерапію з метою переоцінки пацієнтом ситуації, що склалася, та завдань, які постали перед ним, свого стану та компенсаторних можливостей з відмовою від недосяжних, спробою пристосуватися до ситуації.

Результати дослідження. Достовірних відмінностей у здатності стояти на пальцях стопи, найбільшому діаметрі гомілки, подограмі та подографрії стопи, що пов'язують із розвитком гіпотрофрії та зниженням сили м'язів внаслідок

\section{Література}

1. Левенець ВM, Майко ВМ. Ушкодження і захворювання п'яткового (ахіллового) сухожилка [Injuries and diseases of the heel (Achilles) tendon]. Київ; 2010. 216 c. гіподинамії та больового синдрому за такий короткий проміжок час не виявлено; у другій групі відмічено: зменшення об'єму в дистальній частині гомілки на $10 \%$, що підтверджує зменшення набряку в місці розриву; зростання опороспроможності кінцівки на $12 \%$; збільшення сили підошовної фрлексії на $5 \%$; зростання амплітуди рухів та швидкісної витривалості на 8 \%. Відмінності за шкалою Boyden не виявлено, за шкалою AOFAS у другій групі отримано покращення фуннкціональних результатів на $15 \%$.

Висновки. Комплексне використання засобів фозичної реабілітації має переваги порівняно 3 окремим використанням різних методів відновлення. Тільки при систематичному раціональному та комплексному застосуванні засобів фрізичної реабілітації вдається усунути негативні наслідки пошкодження та покращити рухову активність.

Успішне проведення лікувально-відновних заходів потребує участі широкого кола спеціалістів, котрі об'єднані у мультидисциплінарну бригаду з чіткою узгодженістю та координованістю дії для забезпечення цілеспрямованого підходу в реалізації завдань реабілітації.

Головною метою фрізичної реабілітації $\epsilon$ відновлення втрачених кондицій та можливість безпечного повернення до навантажень, що передували травмі. Це потребує розробки та застосування ефективної концепції реабілітації, що включає в себе сучасні методологічні підходи до відновлювального процесу.

Гістологічні зміни взятої під час біопсії тканини не дозволяють оцінювати їх як вторинні, що настали після розриву, першопричиною дегенеративних змін сухожилля $є$ порушення васкуляризації тканини, що потребували застосування медикаментозної корекції.

Остеохондроз поперекового відділу хребта відіграє важливу роль у патогенезі підшкірних розривів за рахунок нейродистрофічних порушень, врахування цієї особливості при реабілітаційних заходах дозволяє швидше відновити втрачену функцію кінцівки.

У ході проведення психотерапії пацієнти досягали впевненості у покращенні свого стану, у готовності до змін образу життя: виконання комплексів лікувальної гімнастики, використання ортеза, регулярне виконання призначень, відвідування фрізіотерапевтичних та процедурних заходів.

2. Середа АП. Хирургическое лечение разрывов ахиллова сухожилия [Surgical treatment for ruptures of the Achilles tendon] [диссертация]. Москва; 2014. 324 с. 
3. Ackermann PW. Neuronal regulation of tendon homoeostasis. International journal of experimental pathology. 2013;94(4):271-86.

4. Ackermann PW, Calder J, Aspenberg P. Healing and Repair Mechanism. In: van Diek CN, Karlsson J, Maffulli N, ThermannH, editors. Achilles Tendon Rupture: DJO Publications; 2008. 17-26.

5. Ackermann PW, Renstrom P. Tendinopathy in sport. Sports Health. 2012;4(3):193-201.

6. Calder J. et al. Disorders of the Achilles tendon insertion. 2012; 218.

7. Calder JD, Saxby TS. Surgical treament of insertional Achilles tendinosis. Foot Ankle Int. 2003;24:119-21.

8. Cook JL, Purdam CR. Rehabilitation of lower limb tendinopathies. Clin Sports Med. 2003;22:777-89.

9. Hess GP, Cappiello WL, Poole RM, Hunter SC. Prevention and treatment of overuse tendon injuries. Sports Med. 1989; 8:371-84.

10. Kakkos SK, Caprini JA, Geroulakos G, Nicolaides AN, Stansby GP, Reddy DJ. Cjmbined intermittent pneumatic leg compression and nikanorov@ukr.net pharmacological prophylaxis for prevention of venous thromboembolism in high-risk patients. Cochrane Database Syst Rev. 2008;(4): CD005258.

11. Karlsson J., et al. Achilles tendon disorders. 2014; 426.

12. Kountouris A, Cook J. Rehabilitation of Achilles and patellar tendinopathies. Best practice \& research Clinical rheumatology. 2007; 21:295316.

13. Maffulli N, Walley G, Sayana MK, Longo UG, Denaro V. Eccentric calf muscle training in athletic patients with Achilles tendinopathy. Disabil Rehabil. 2008; 30:1677-84.

14. Maffulli N, Oliva F. Achilles tendon. 2009; 105

15. Magnusson SP, Langberg $H$, Kjaer $M$. The pathogenesis of tendinopathy: balancing the response to loading. Nat Rev Rheumatol. 2010;6(5):262-8.

Надійшла 10.08.2020 